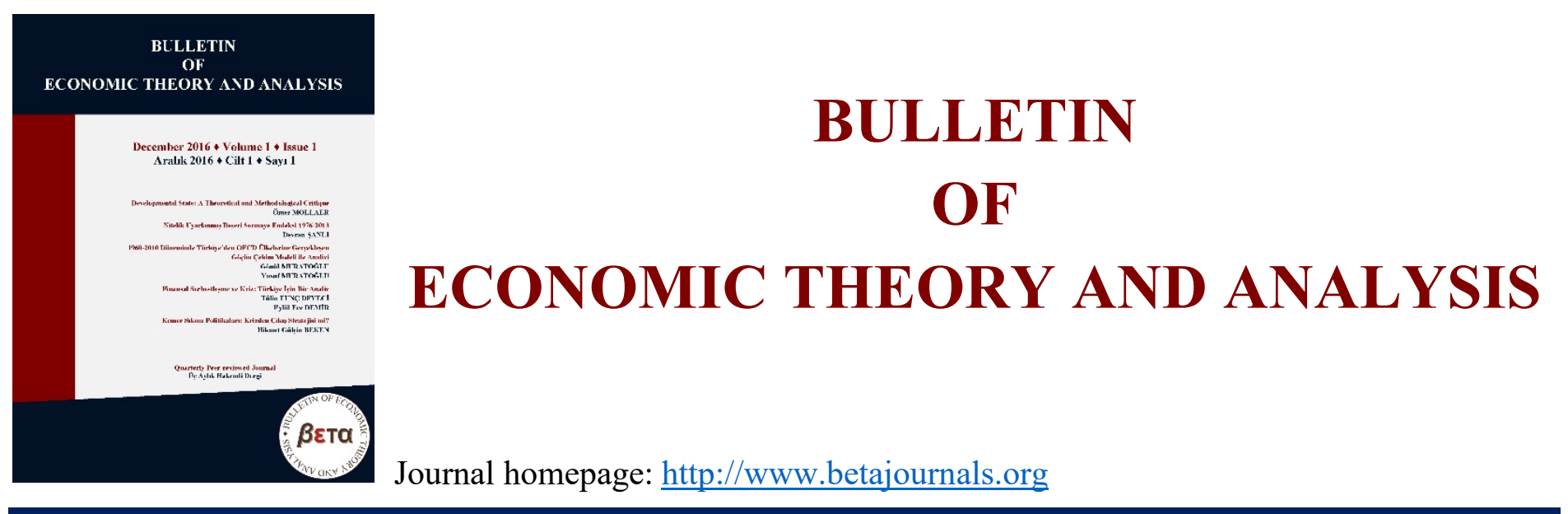

\title{
Genç Nüfusta İşsizlik Histerisinin Sınanması: Türkiye Örneği
}

Nuran COŞKUN ๑ https://orcid.org/0000-0002-7803-7968

To cite this article: Coşkun, N., (2021). Genç Nüfusta İşsizlik Histerisinin Sınanması: Türkiye Örneği. Bulletin of Economic Theory and Analysis, 6(1), 97-112.

Received: 07 Mar 2020

Accepted: 25 May 2021

Published online: 30 Jun 2021

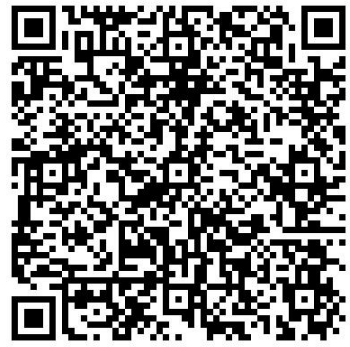




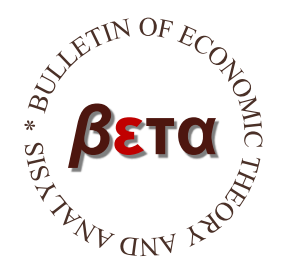

\title{
Bulletin of Economic Theory and Analysis
}

Volume VI, Issue 1, pp. 97-112, 2021

http://www.betajournals.org

Original Article / Araştırma Makalesi

Received / Alınma: 07.03.2021 Accepted/Kabul: 25.05.2021

\section{Genç Nüfusta İşsizlik Histerisinin Sınanması: Türkiye Örneği}

\author{
Nuran COŞKUN ${ }^{\mathrm{a}}$ \\ ${ }^{a}$ Arş. Gör. Dr., Mersin Üniversitesi, İIBF, İktisat Bölümü, Mersin, TÜRKIYYE \\ (C) https://orcid.org/0000-0002-7803-7968
}

\section{ÖZ}

İşsizlik oranları en önemli makroekonomik göstergelerden biridir. Büyüme, refah, gelir gibi diğer makroekonomik göstergeler üzerinde doğrudan ve/veya dolaylı etkileri olması nedeniyle oldukça çok sayıda çalışmaya konu olmaktadır. Bu çalışmada üniversite mezunu genç nüfusta cinsiyet değişkenini de dikkate alınarak, işsizlik histerisi araştırılmıştır. Genç işsizlerde histerinin araştırılmasında zaman serisi yöntemi kullanılmıştır. 15-24 yaş grubundaki nüfusun cinsiyete dayalı işe katılım oranı ve işsizlik oranı 2014:01-2020:09 arası aylık verileri kapsamaktadır ve elde edilen bulgular, Türkiye'de genç nüfusta ADF test istatistikleri işsizlik histerisini destekler yöndedir. Ani kırılmalar dikkate alındığında (Zivot \& Andrews, 1992 ve Narayan \& Popp, 2010) yapısalcı yaklaşımın geçerli olduğu sonucu elde edilmiştir. Diğer yandan, yumuşak kırılmalar dikkate alındığında hem yapısalcı yaklaşımı hem de histeri etkisini destekler yönde karışık bulgular elde edilmiştir.

Anahtar Kelimeler Genç İşsizlik Oranı, Histeri, Doğal Oran Hipotezi

JEL Kodu

E24, J21, J23

\footnotetext{
İLETIŞSiM Nuran COȘKUN $₫$ nuran coskun@windowslive.com $\equiv$ Mersin Üniversitesi, İ̈BF, İktisat
} Bölümü, Mersin, TÜRKIYYE 


\title{
Testing the Hysteresis in Youth Unemployment: The Case of Turkey
}

\begin{abstract}
Unemployment rate is one of the most important macroeconomic indicators. As a result of that substantial number of studies investigate unemployment rate and its hysteria since it has direct and indirect effects on the other macroeconomic indicators such as growth, income and wealth. The aim of this study is to investigate unemployment rate and its hysteria among the youth unemployment with graduated from university in Turkey with taking into consider gender. Time series methods are utilized to test the hysteria for youth unemployment population. The gender-based job participation rate and unemployment rate of the youth population in the 15-24 age is used for testing hysteresis in youth unemployment between 2014: 01-2020: 09 and the finding reveals that, hysteresis hypothesis is valid for youth population even taking into consider gender according to ADF test statistics. On the other hand, taking into consider sharp breaks (Zivot \& Andrews, 1992 and Narayan \& Popp, 2010) structuralist approach to natural hypothesis is valid. However, fourier ADF test results both support structuralist approach and hysteresis together. Therefore, as a conclusion this test has mixed results.
\end{abstract}

Keywords

Youth

Unemployment

Rate, Hysteresis, Natural Rate

Hypothesis

JEL Classification

$\mathrm{E} 24, \mathrm{~J} 21, \mathrm{~J} 23$

\section{Giriş}

Phillips eğrisi, enflasyon ve işsizlik oranlarının ters ilişkili olduğunu iddia etmektedir. Phelps (1968) ve Friedman (1968) tarafından önerilen doğal işsizlik oranı hipotezi ise, makroekonomik bir şok karşısında yaşanan işsizlik oranı artışının uzun dönemde denge seviyesine döneceği şeklindedir. Ancak, 1973 yılında petrol ihraç eden ülkeler birliğinin üretim azaltma kararıyla, dünya çapında üretim maliyetlerinde bir artış yaşandı. Ham madde fiyatlarındaki artışın üretim maliyetlerine yansımasıyla, üretim azaldı ve üretimdeki düşüşler, işsizlik oranlarının artmasıyla sonuçlandı. Diğer yandan hammadde fiyatlarındaki artış, üretimin azalmasına ve maliyet artışına neden olarak üretici ve tüketici fiyatlarını arttırdı ve yüksek enflasyon seviyelerine yol açtı. Bu durum, o güne kadar genel geçer kabul edilen Phillips eğrisinin, Phelps (1968) ve Friedman (1968) tarafından önerilen doğal işsizlik oranı hipotezinin eleştirilmeye başlamasına neden oldu. Nelson ve Plosser (1982), Campbell ve Mankiw (1986) gibi Blanchard ve Summers (1986) işsizlik oranlarının rassal süreç izlediğini yani, bir şok karşısında ortalamasına dönme eğiliminde olmadığını savundular. Blanchard ve Summers (1986), içeridekiler ve dışarıdakiler (çalışanlar ve çalışmayanlar) üzerinden geliştirdikleri modelle, firmalar tarafından belirlenen ücretlerde daha çok içeridekilerin etkili olduğunu savundular. Böylece bu model üzerinden işsizlik histerisi durumuna açıklık getirmeye çalışmışlardır. Phelps (1994) önerdiği yapısalcı yaklaşımda, 
işsizlik üzerindeki şokun yapısal kırılmalar dikkate alındığında geçici ve yapısal kırılmalar altında çok az şokun doğal işsizlik oranını kalıcı olarak değiştirebileceğini iddia etmiştir. Sonuç olarak teoride, üç temel yaklaşım ortaya çıkmaktadır. İşsizlik oranlarının ortalamasına dönme eğiliminde olduğunu savunan doğal oran hipotezi ve yapısal kırılmaları dikkate altında işsizlik oranlarının ortalamasına döndüğünü iddia eden yapısalcı yaklaşım, işsizlik oranlarının ortalamasına dönme eğiliminde olduğu savunan ilk iki yaklaşımı oluşturmaktadır. Üçüncü yaklaşım ise, işsizlik oranlarının ortalamasına dönmediği durumu tartışan işsizlik histerisidir. Bu görüşler ışığında, birim kök testinden yararlanarak genç nüfusta işsizlik serisinin durağanlığı araştırılmıştır. Bu görüşler 1şığında, birim kök testinden yararlanarak genç nüfusta işsizlik serisinin durağanlığı araştırılmıştır. Bu çalışmalar ışı̆̆ında, Türkiye'de genç nüfusta işsizlik oranlarının durağanlığı, 2014:01-2020:09 dönemi arası için araştırılmıştır. Bu çalışmada, teorik literatürde yer alan doğal oran hipotezi, yapısalcı yaklaşım ve histeri etkisi yaklaşımlarını beraber dikkate alacak şekilde farklı birim kök testleri kullanılarak (ADF, Zivot \& Andrews (1992), Narayan \& Popp (2010) ve Enders \& Lee (2012)) genç işsizlik serisinin durağanlığı test edilerek literatüre katkıda bulunulması amaçlanmıştır. Elde edilen bulgular, ani kırılmaların dikkate alınması durumunda yapısalcı yaklaşımın geçerli olduğunu göstermektedir.

\section{Literatür: Türkiye’de Genç Nüfusta İşsizlik Oranlarında Yapısalcı Yaklaşım}

Doğal oran hipotezi, yapısalcı yaklaşım ve histeri etkisi olmak üzerek bu üç farklı görüş 1şığında, birim kök testinden yararlanarak genç nüfusta işsizlik serisinin durağanlığını araştıran literatürde çok sayıda çalışma bulunmaktadır. Türkiye için de birim kök testi ile işsizlik oranlarının ortalamasına dönem eğiliminde olup olmadığını araştıran çok sayıda çalışma bulunmaktadır. Bu bağlamda yapısalcı yaklaşım çerçevesinde kırılmaları da dikkate alarak yapılan çalışmalardan, Barışık ve Çevik (2008), Yılancı (2009), Yıldırım (2011), Kahyaoğlu vd. (2016), Tekin (2018), Sigeze vd. (2019) Türkiye için işsizlik histerisi hipotezinin geçerli olduğu sonucuna ulaşmıştır. Çemrek ve Şeker (2020) kadınlarda işsizlik histerisinin geçerli olduğu sonucuna ulaşmıştır. Diğer yandan, Çınar vd. (2014) yapısalcı yaklaşımın Türkiye için geçerli olduğu sonucuna ulaşmıştır. Saraç (2014) ve Topalhan vd. (2017), yapısal kırılmalar dikkate alınmadığında işsizlik histerisinin geçerli olduğunu ancak yapısal kırılmalar dikkate alındığında doğal oran hipotezinin geçerli olduğunu dolayısıyla Türkiye'de yapısalcı yaklaşımın geçerli olduğunu bulmuşlardır. Öztürk (2020) ise, işgücüne katılım, istihdam ve genç işsizlik serileri için işsizlik hipotezinin geçerli olduğu ancak genel ve tarım dışı işsizlik verileri için yapısalcı yaklaşımın geçerli olduğu sonucunu 
elde etmiştir. Akcan (2019) ise, genç işsizlik oranlarının genel işsizlik oranlarına göre daha fazla histeri etkisini barındırdığı tespit etmiştir.

\section{Veri ve Yöntem}

Genç işsizlik oranı, 15-24 yaş arasındaki çalışmak istedikleri halde iş bulamayan işsizlerin, 15-24 yaş arasındaki toplam işgücü içindeki payı olarak ifade edilmektedir. Türkiye yaklaşık 11 milyon ne istihdamda ne de eğitimde olan bir genç nüfusa sahiptir. Türkiye İstatistik Kurumu'ndan (TÜİK) elde edilen verilere göre, Ağustos 2020 itibariyle ne istihdamda ne eğitimde olan genç nüfus toplam 11728 kişidir. Bu nüfusun \%51'i erkek, \%49'u kadınlardan oluşmaktadır. Tablo 1'e göre ne eğitimde ne istihdamda olan genç nüfusun \%1'i okur yazar değilken, lise altı eğitim almış olanlar \%51, lise eğitimi almış olan \%19, mesleki veya teknik lise mezunu \%15, yüksekokul mezunu \%12 civarındadır. Genç nüfusu yüksek bir ülke olarak, işsizlik histerisinin genç nüfusta yüksek olması durumunda, istihdamı arttıracak politikalar öne çıkmaktadır. Bu nedenle bu çalışmada, 15-24 yaş arası nüfusta işe katılım oranı (tisko) ve işsizlik oranı (tio) verileriyle toplam genç nüfus için işsizlik histerisi araştırılmıştır. Ayrıca ele alınan yaş aralığı nedeniyle, kadın ve erkek istihdamı arasındaki farklılıklar, cinsiyete göre de bir ayrıma gidilmesi gerektiğini gösterdiğinden, 15-25 yaş arası nüfus için kadın işe katılım oranı (kisko), kadın işsizlik oranı (kio), erkek işe katılım oranı (eisko), erkek işsizlik oranı (eio) verileriyle de analizler tekrar edilmiştir. Çalışmada kullanılan veriler, TÜİK istatistik günlüklerinden elde edilmiş olup, 15-24 yaş grubundaki nüfusun cinsiyete dayalı işe katılım oranı ve işsizlik oranı 2014:01-2020:09 arası aylık verileri kapsamaktadır.

Şekil 1, 15-24 yaş arası genç nüfusun işe katılım (tisko) ve işsizlik oranı (tio), 15-24 yaş arası genç nüfusta kadınların işe katılım (kisko) ve işsizlik oranını (kio) ve 15-24 yaş arası genç nüfusta erkeklerin işe katılım (eisko) ve işsizlik oranlarını (eio) göstermektedir. Grafikte mevsimsel etkiler dikkat çekmektedir. Bu nedenle çalışmada analizde kullanılan veri seti ilk olarak mevsimsel etkiden arındırılmıştır. Mevsimsel etkiden arındırılmamış, ham veriler için betimleyici istatistikler Tablo 2'de ve grafik ise Şekil 2'de yer almaktadır. Tablo 2'ye göre, 15-24 yaş arası genç nüfusun işe katılım oranı için (tisko) en büyük değer 47.94, minimum değer 34.48, ortalama 42.35 ve standart sapma 2.81 olarak bulunurken, işsizlik oranı (tio) için ilgili dönemde aldığı maksimum değer 27.43, minimum değer 15.50, ortalama 20.93 ve standart sapma 3.17 olarak bulunmuştur. 15-24 yaş arası genç nüfusta kadınların işe katılım oranı (kisko) için en büyük değer, 
34.59, en küçük değer 23.8, ortalama 30.13 ve standart sapma 2.39 olarak hesaplanırken ilgili dönemde işsizlik oranını (kio) için maksimum değer 34.60, minimum değer 16.50, ortalama 25.24 ve standart sapma 4.11 'dir.

Tablo 1

Ne Eğitimde Ne İstihdamda Olan (15- 24 Yaş) Genç Nüfusun Bitirdiği Ĕ̈itim Düzeyi

\begin{tabular}{lccccc}
\hline Toplam & $\begin{array}{c}\text { Okur-Yazar } \\
\text { Olmayanlar }\end{array}$ & $\begin{array}{c}\text { Lise Altı } \\
\text { Eğitimler }\end{array}$ & Lise & $\begin{array}{c}\text { Mesleki veya } \\
\text { Teknik Lise }\end{array}$ & Yüksekokul \\
\hline 11728 & 170 & 6067 & 2263 & 1802 & 1426 \\
\hline Yüzde & 0.01 & 0.52 & 0.19 & 0.15 & 0.12 \\
\hline
\end{tabular}

Kaynak. Türkiye İstatistik Kurumu İstatistik Günlükleri

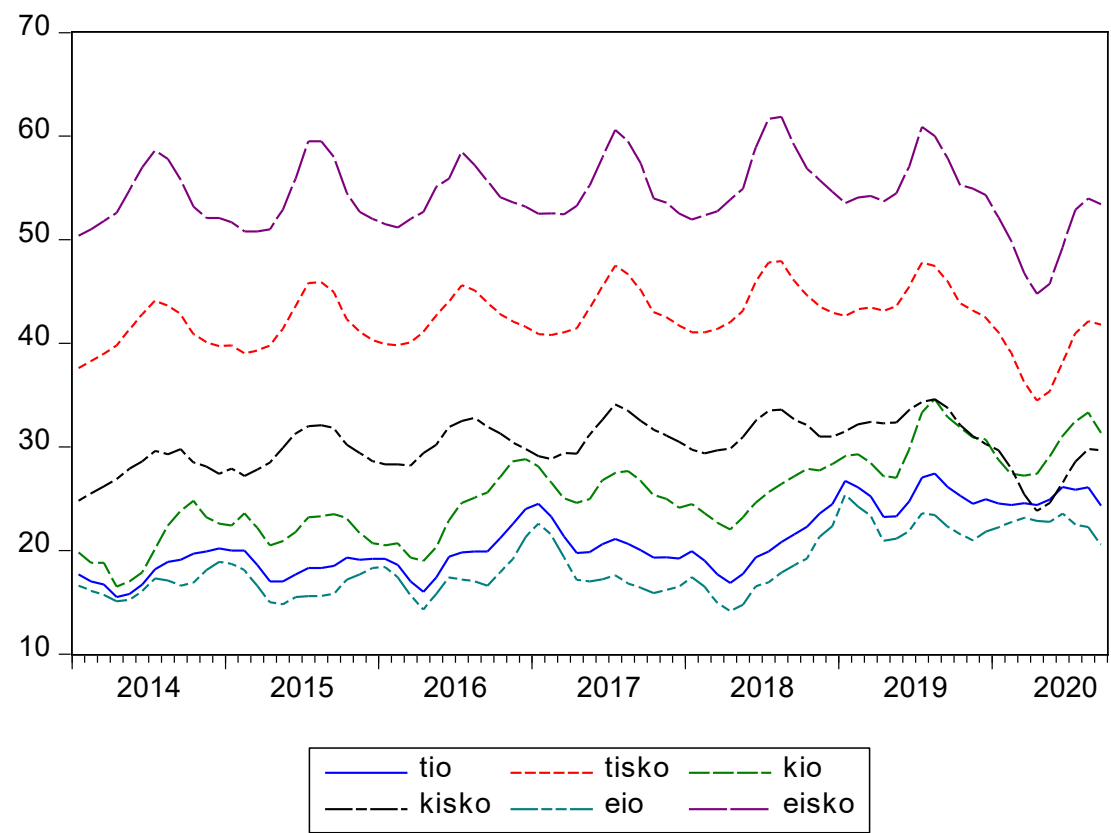

Şekil 1. Genç Nüfusun Cinsiyete Dayalı İşe Katılım ve İşsizlik Oranları

15-24 yaş arası genç nüfusta erkeklerin işe katılım oranı (eisko) için ilgili dönemde bulunan en büyük değer, 53.98, en küçük değer 44.77, ortalama 54.25 ve standart sapma 3.39 olarak hesaplanmıştır. Diğer yandan, 15-24 yaş arası genç nüfusta erkeklerin işsizlik oranlarını (eio) için en büyük değer 25.37, en küçük değer 14.10, ortalama 18.58 ve standart sapma 2.91 olarak bulunmuştur. Tabloya göre, sırasıyla 15-24 yaş arası genç nüfusta işe katılım oranı ve işsizlik oranı, kadın genç nüfusta işe katılım oranı ve işsizlik oranı, erkek genç nüfusta işe katılım ve işsizlik oranı için medyan 19.91, 42.47, 24.97, 29.90, 17.43, 53.98'dir. Şekil 2, bu serilerin mevsimsel etkiden arındırılmış grafiklerini göstermektedir. 
Tablo 2

15-24 Yaş Arası Genç Nüfusun İşe Katılım ve İşsizlik Oranlarına İlişkin Betimleyici İstatistikler (2014:01-2020:09)

\begin{tabular}{lcccccc}
\hline & TIO & TISKO & KIO & KISKO & EIO & EISKO \\
\hline Ortalama & 20.93 & 42.35 & 25.24 & 30.13 & 18.58 & 54.35 \\
Medyan & 19.91 & 42.47 & 24.97 & 29.90 & 17.43 & 53.98 \\
Maximum & 27.43 & 47.94 & 34.60 & 34.59 & 25.37 & 61.87 \\
Minimum & 15.50 & 34.48 & 16.50 & 23.83 & 14.10 & 44.77 \\
Standart Sapma & 3.17 & 2.81 & 4.11 & 2.39 & 2.91 & 3.39 \\
\hline
\end{tabular}

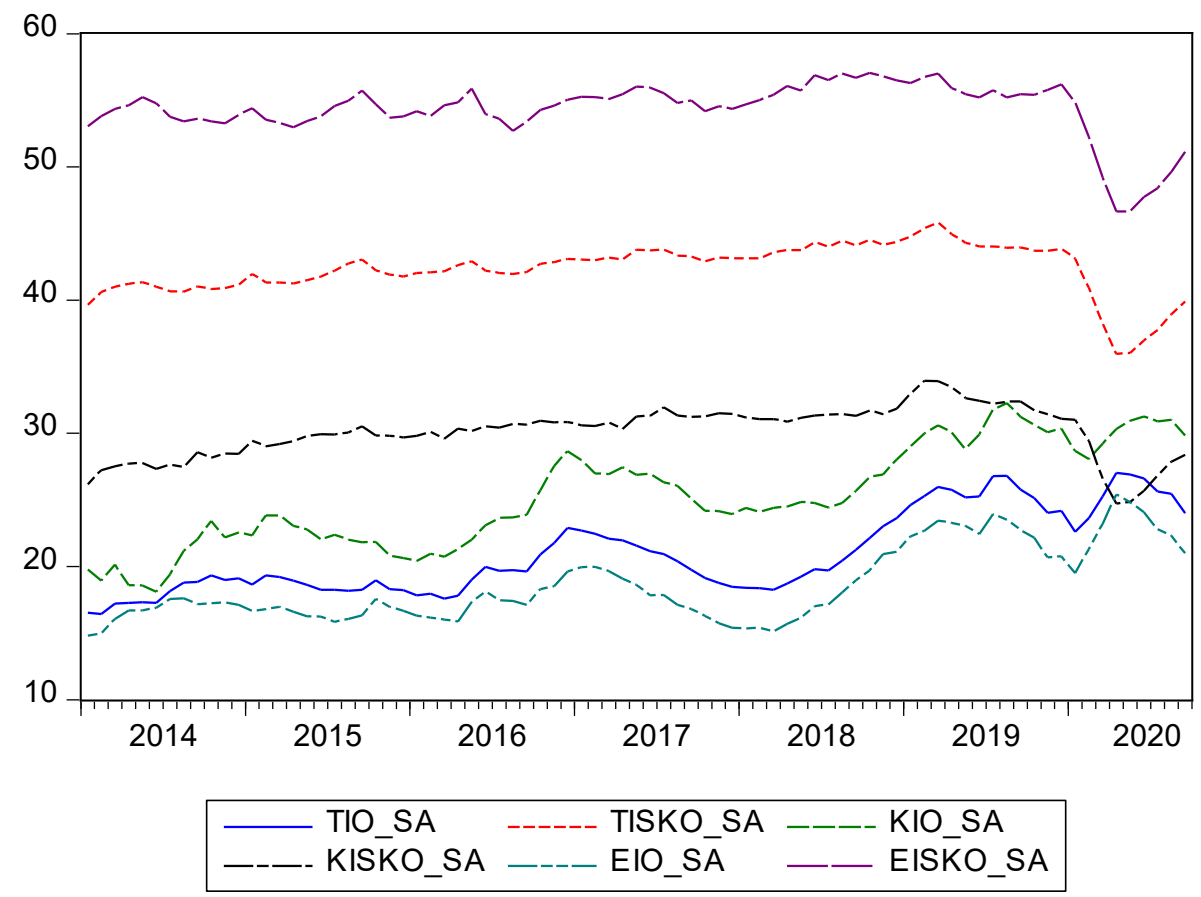

Şekil 2. Genç Nüfusun Cinsiyete Dayalı İşe Katılım ve İşsizlik Oranları: Mevsimsel Etkiden Arındırılmış

Dickey \& Fuller (1979;1981) birim kök testi aşağıdaki AR (1) süreci denklemine dayanır.

$$
Y_{t}=\alpha+\rho Y_{t-1}+e_{t}
$$

Burada $t=2,3, \ldots, n$, olmak üzere zamanı ve $e_{t}$ ise sıfir ortalamalı sabit varyanslı normal bağımsız rassal süreci ifade etmektedir. Dickey ve Fuller (1979) yukarıdaki regresyonda rassal süreci ifade eden Model C, sabit terimin bulunduğu Model B ve hem sabit hem de trend teriminin bulunduğu Model A olmak üzere, farklı deterministik birleşenlerin bulunduğu modelleri tanımlamışlardır. Bu 
bağlamda denklem, son olarak kalıntılardaki seri korelasyonunu gidermek amacıyla bağımlı değişkenin gecikmeleri de modele eklenerek aşağıdaki son halini almıştır.

$$
\triangle Y_{t}=\zeta d_{t}^{\prime}+\gamma Y_{t-1}+\sum \beta_{i} \stackrel{\rho}{\rho} Y_{t-i}+e_{t}
$$

$\mathrm{Bu}$ denklemde $d_{t}^{\prime}$ deterministik birleşeni ifade etmekte olup, rassal süreç için bu terim bulunmamaktadır ve Model C olarak adlandırılmaktadır. Sadece sabit terimin bulunduğu model, Model B $\left(d_{t}^{\prime}=[1]\right)$ ve sabit ve trend teriminin bulunduğu model, Model A $\left(d_{t}^{\prime}=[1, t]\right)$ olarak adlandırılmaktadır. Diğer yandan, ADF testi serilerdeki kırılmaları dikkate almamaktadır. Zivot ve Andrews (1992) (ZA) ADF testine sabit ve trend kırılmaları da dahil etmiştir. Sabitte kırılma olması durumunda, sabit kırılmasına ait kukla değişken (DU) deterministik terime eklenmektedir $\left(d_{t}^{\prime}=[1, t, D U]\right)$. Sabit ve trendde kırılma olması durumunda, sabit ve trend için kukla değişkenler (DU, DT) deterministik terime eklenmektedir $\left(d_{t}^{\prime}=[1, t, D U, D T]\right)$. Zivot ve Andrews (1992) boş hipotezi serileri dışsal bir kırılmanın varlığında birim kök içermektedir diye oluşturmuşlardır. Yapısal kırılmanın olduğu tarih, T zamanın maksimum değeri olmak üzere $1<T_{B}<T$ şeklinde tanımlıdır. Diğer yandan, alternatif hipotez ise dışsal bir yapısal kırılmanın varlığında seri durağandır şeklinde ifade edilmektedir. Yapısal kırılma kuklaları sabit kuklası ve trend kuklası olmak üzere şu şekilde tanımlıdır: $D U=1$ eğer $t>T_{B}, 0$ diğer durumda ve $D T=1$ eğer $t>$ $T_{B}, 0$ diğer durumda.

Narayan ve Popp (2010) serilerde iki kırılma olması durumuda ADF testinin iki kırılmalı durumunu geliştirmişlerdir. Narayan ve Popp (2010; 2013), iki kırılmalı durumu iki farklı model için geliştirmiştir. İlk modelde (M1) sabitte iki kırılmaya izin verilirken ikinci (M2) sabitte ve kırılmada iki kırılmaya izin verilmektedir. Bu durumda M1 modelinin deterministik birleşimi şu şekilde ifade edilmişstir: $d_{t}^{M 1}=\left[1, t, D U_{1, t}^{\prime}, D U_{2, t}^{\prime}\right]$. Diğer yandan M2 modeli için deterministik birleşen ise and $=\left[1, t, D U_{1, t}^{\prime}, D U_{2, t}^{\prime}, D T_{1, t}^{\prime}, D T_{2, t}^{\prime}\right]$ şeklinde ifade edilmiştir. Burada $D U_{i, t}^{\prime}=$ $1\left(t>T_{B, i}^{\prime}\right), D T_{i, t}^{\prime}=1\left(t>T_{B, i}^{\prime}\right)\left(t-T_{B, i}^{\prime}\right)$ iken $T_{B, i}^{\prime} i=1,2$ olmak üzere kırılma tarihidir. Narayan \& Popp (2010) kırılma tarihlerinin bilinmediği ve çift olarak aynı anda seçildiği varsayımıyla kırılma tarihlerini belirleyen bir süreç takip etmektedir.

Enders ve Lee (2012) çalışmasında da kullanılan temel model ADF testine dayanmaktadır. $\mathrm{Bu}$ çalışmada da ADF testinde tahmin edilen regresyon modeline fourier fonksiyonları deterministik birleşen olarak dahil edilmiştir. Bu çalışmada da iki model bulunmaktadır. İlk model 
(Model 1) sabit terimin bulunduğu model olup, ikinci model (Model 2) trend ve sabit terimi birlikte içermektedir. Model 1 için deterministik terim şu şekildedir: $d_{t}^{\text {Model } 1}=\left[1, \sin \left(\frac{2 \pi k t}{T}\right)+\right.$ $\left.\cos \left(\frac{2 \pi k t}{T}\right)\right]$. Model 2 için ise deterministik terim $\quad d_{t}^{\text {Model } 2}=\left[1, t, \sin \left(\frac{2 \pi k t}{T}\right)+\cos \left(\frac{2 \pi k t}{T}\right)\right]$ şeklinde tanımlanmıştır. Burada T gözlem sayısı, k spesifik bir sıklık değeri olma üzere trend teriminin bulunmadığı deterministik birleşen aşağıdaki gibidir:

$$
d_{t}^{\prime}=\alpha_{0}+\sum_{k=1}^{n} \alpha_{k} \sin \left(\frac{2 \pi k t}{T}\right)+\sum_{k=1}^{n} \beta_{k} \cos \left(\frac{2 \pi k t}{T}\right) ; \quad n \leq \frac{T}{2}
$$

Spesifik k sıklık değerinin belirlenmesinde ilk olarak 1 ve 5 arasındaki tüm modeller tahmin edilir ve en küçük hata kareleri toplamına sahip model için elde edilen k değeri uygun k değeri olarak belirlenir. Enders ve Lee (2012)'ye göre, eğer ki seri doğrusal ise ADF testi daha uygunken, seride bir kırılma veya doğrusal olmayan bir trend olması durumunda veri yaratma sürecinde en az $\mathrm{k}=1$ olan bir fourier fonksiyonu bulunmaktadir.

\section{Bulgular ve Tartışma}

İşsizlik oranlarında temelde karşılaşılabilecek üç durum ve bu durumları açıklamaya yönelik üç temel yaklaşım bulunmaktadır. İşsizlik oranlarının ortalamasına dönme eğiliminde olduğunu savunan doğal oran hipotezi ve geleneksel birim kök testlerinin yapısal kırılmaları dikkate almadığını ancak bazı şoklar karşısında yapısal kırılmaları dikkate aldığımızda işsizlik oranlarının ortalamasına dönme eğiliminde olacağını iddia eden yapısalcı yaklaşım ve son olarak, işsizlik oranlarının ortalamasına dönmediği durumu tartışan işsizlik histerisi yaklaşımıdır. Çalışmada serilerin durağanlığı ilk olarak ADF birim kök testi ile sınamıştır, Kırılmaları dikkate almayan geleneksel bir birim kök testi olan ADF test istatistikleri Tablo 3'de yer almaktadır. Tablo 3' de model C, rassal süreci, Model B deterministik birleşen olarak sabit terimin bulunduğu modeli, Model A, deterministik birleşen olarak sabit terimin ve trend teriminin bulunduğu modeli ifade etmektedir. Model $\mathrm{C}^{*}$ ise serilerin birinci farkı alındığında rassal model için uygulanan test istatistiğini ve olasılık değerini içermektedir. Tablodan elde edilen sonuçlara göre, \%5 önem düzeyinde serilerin birim kök içerdiği yönündeki boş hipotez reddedilemediğinden serilerin birim kök içerdiği ancak farkı alındığında durağan olduğu sonucu elde edilmiştir. ADF testine göre, cinsiyet ayrımı olmaksızın, genç nüfusta işsizlik histerisi geçerlidir. 
Tablo 3.

15-24 Yaş Arası Genç Nüfusun İşe Katılım ve İssizlik Oranları- ADF Birim Kök Test Sonuçları

\begin{tabular}{llcccc}
\hline \multirow{2}{*}{ Değişken } & & \multicolumn{4}{c}{ Model } \\
\cline { 3 - 6 } & & Model C & Model B & Model A & Model C* \\
\hline TIO_SA & t-ist & -0.2423 & -1.8297 & -2.59466 & -5.66711 \\
& Olas1l1k & 0.5958 & 0.3637 & 0.2839 & 0 \\
TISKO_SA & t-ist & -0.2423 & -2.79561 & -2.7607 & -5.53457 \\
& Olas1l1k & 0.5958 & 0.0635 & 0.2162 & 0 \\
KIO_SA & t-ist & 0.833197 & -1.70119 & -2.8591 & -6.62295 \\
& Olas1l1k & 0.8891 & 0.4268 & 0.1814 & 0 \\
KISKO_SA & t-ist & -0.01048 & -2.29673 & -2.12334 & -5.71827 \\
& Olasil1k & 0.6762 & 0.1756 & 0.5248 & 0 \\
EIO_SA & t-ist & 0.325462 & -1.44552 & -3.14684 & -5.06203 \\
& Olasil1k & 0.777 & 0.5557 & 0.1031 & 0 \\
EISKO_SA & t-ist & -0.44141 & -2.8119 & -2.82861 & -5.46989 \\
& Olasil1k & 0.5202 & 0.0611 & 0.1917 & 0 \\
\hline
\end{tabular}

Not. *Bu model fark alınmış değişkenler için elde edilen sonuçları içermektedir.

Tablo 3, ADF test istatistik sonuçlarını içermektedir. Elde edilen bulgular, cinsiyet ayrımı gözetmeksizin serilerin \%5 önem düzeyinde birim kök içerdiğini göstermiştir. Bu bulgular ışı̆̆ında kırılmaları da dikkate alarak, birim kök testleri tekrar edilmelidir. Böylece işsizlik histerisinin genç nüfusta kesin varlığı sonucuna varmadan önce yapısalcı yaklaşım açısından da değerlendirilmiş olacaktır.

Bu bağlamda Tablo 4, ani kırılmalı birim kök test sonuçlarını içermektedir. Tablo 4'e göre tek kırılmalı ve iki kırılmalı testlerde \%5 önem düzeyinde toplam işsizlik oranı (TIO_SA), kadınlarda işsizlik oranı (KIO_SA), erkeklerde işsizlik oranı (EIO_SA) serilerinde ve toplam işgücüne katılım oranı (TİSKO_SA), kadınlarda işgücüne katılım oranı (KISKO_SA) ve erkeklerde toplam işgücüne katılım oranı (EİSKO_SA) serileri için yapısal kırılmanın varlığında serilerin birim kök içerdiği şeklindeki boş hipotez reddedildiğinden, seriler seviyede durağandır. Bu durum yapısalcı yaklaşımı doğrulamaktadır. Diğer yandan Tablo 5, Fourier ADF birim kök testi sonuçlarını içermektedir. Sabitli model için serilerin birim kök içerdiği yönündeki boş hipotez \%5 önem düzeyinde reddedilemezken, kadınlar için işgücüne katılım oranı (KISKO_SA) serisi hariç, diğer serilerde sabitli ve trendli modelde boş hipotez \%5 önem düzeyinde reddedilmektedir. Ayrıca, Şekil 3 ve Şekil 4 sırasıyla k=1 ve k=3 için sabit ve trend içeren fourier fonksiyonlarının seri ile birlikte grafiklerini içermektedir. 
Tablo 4

Ani Kırılmalı Birim Kök Test Sonuçları

\begin{tabular}{|c|c|c|c|c|c|}
\hline \multirow[t]{2}{*}{ Değişken } & \multirow[t]{2}{*}{ Test } & \multicolumn{2}{|c|}{$\begin{array}{c}\text { Zivot \& Andrews (1992) } \\
\text { Bir kırılma }\end{array}$} & \multicolumn{2}{|c|}{$\begin{array}{c}\text { Narayan \& Popp (2010) } \\
\text { İki kırılma }\end{array}$} \\
\hline & & Sabit & Sabit \&Trend & Sabit & Sabit \&Trend \\
\hline \multirow{5}{*}{ TIO_SA } & ADF- test istat. & -5.338 & -6.365 & -5.83 & -6.019 \\
\hline & Kırılma Tarihi & 72 & 73 & $21 ; 40$ & $32 ; 53$ \\
\hline & Fraksiyon & 0.889 & 0.901 & $0.259 ; 0.494$ & $0.395 ; 0.654$ \\
\hline & \%5 kritik değer & -3.69 & -3.69 & -4.07 & -4.78 \\
\hline & Gecikme & 10 & 8 & 8 & 8 \\
\hline \multirow{5}{*}{ TISKO_SA } & ADF- test istat. & -8.066 & -7.193 & -4.327 & -7.259 \\
\hline & Kırılma Tarihi & 71 & 64 & $29 ; 66$ & $24 ; 64$ \\
\hline & Fraksiyon & 0.877 & 0.79 & $0.358 ; 0.815$ & $0.296 ; 0.790$ \\
\hline & \%5 kritik değer & -3.69 & -3.75 & -4.08 & -4.6 \\
\hline & Gecikme & 1 & 3 & 1 & 4 \\
\hline \multirow{5}{*}{ KIO_SA } & ADF- test istat. & -5.626 & -6.64 & -6.925 & -7.564 \\
\hline & Kırılma Tarihi & 41 & 52 & $52 ; 64$ & $32 ; 58$ \\
\hline & Fraksiyon & 0.506 & 0.642 & $0.642 ; 0.79$ & $0.395 ; 0.716$ \\
\hline & $\% 5$ kritik değer & -3.76 & -3.76 & -4.11 & -4.78 \\
\hline & Gecikme & 12 & 12 & 12 & 12 \\
\hline \multirow{5}{*}{ KISKO_SA } & ADF- test istat. & -5.149 & -5.712 & -5.053 & -6.388 \\
\hline & Kırılma Tarihi & 72 & 72 & $23 ; 61$ & $49 ; 65$ \\
\hline & Fraksiyon & 0.889 & 0.802 & $0.284 ; 0.753$ & $0.605 ; 0.802$ \\
\hline & $\% 5$ kritik değer & -3.69 & -3.75 & -4.11 & -4.57 \\
\hline & Gecikme & 12 & 12 & 12 & 12 \\
\hline \multirow{5}{*}{ EIO_SA } & ADF- test istat. & -5.125 & -5.533 & -5.932 & -5.732 \\
\hline & Kırılma Tarihi & 70 & 40 & $21 ; 40$ & $21 ; 40$ \\
\hline & Fraksiyon & 0.864 & 0.494 & $0.259 ; 0.494$ & $0.259 ; 0.494$ \\
\hline & $\% 5$ kritik değer & -3.69 & -3.76 & -4.11 & -4.57 \\
\hline & Gecikme & 8 & 8 & 8 & 8 \\
\hline \multirow{5}{*}{ EISKO_SA } & ADF- test istat. & -6.958 & -6.46 & -4.076 & -6.633 \\
\hline & Kırılma Tarihi & 71 & 64 & $31 ; 45$ & $56 ; 64$ \\
\hline & Fraksiyon & 0.877 & 0.79 & $0.383 ; 0.556$ & $0.691 ; 0.79$ \\
\hline & \%5 kritik değer & -3.69 & -3.75 & -4.07 & -4.57 \\
\hline & Gecikme & 2 & 1 & 3 & 4 \\
\hline
\end{tabular}

Tablo 5

Yumuşak Kırllmalı Birim Kök Testi (Fourier ADF)

\begin{tabular}{clcccccc}
\hline Enders \& Lee (2012) & TIO_SA & TISKO_SA & KIO_SA & KISKO_SA & EIO_SA & EISKO_SA \\
\hline \multirow{4}{*}{ Sabit } & ADF-istat & -0.3594 & -3.8069 & 0.2681 & -1.7785 & -2.9446 & -3.3661 \\
& Fourier(k) & 3 & 1 & 3 & 3 & 1 & 1 \\
& Gecikme & 1 & 1 & 3 & 1 & 1 & 1 \\
& \%5 Kritik Değer & -3.78 & -4.35 & -3.78 & -3.78 & -4.35 & -4.35 \\
\hline \multirow{2}{*}{ Sabit } & ADF-istat & -3.2096 & -4.0095 & -4.9563 & -2.4948 & -3.4667 & -4.1171 \\
\multirow{2}{*}{ \& } & Fourier(k) & 3 & 1 & 2 & 1 & 3 & 1 \\
& Gecikme & 1 & 1 & 9 & 3 & 2 & 1 \\
& \%5 Kritik Değer & -3.07 & -3.81 & -3.27 & -3.81 & -3.07 & -3.81 \\
\hline
\end{tabular}



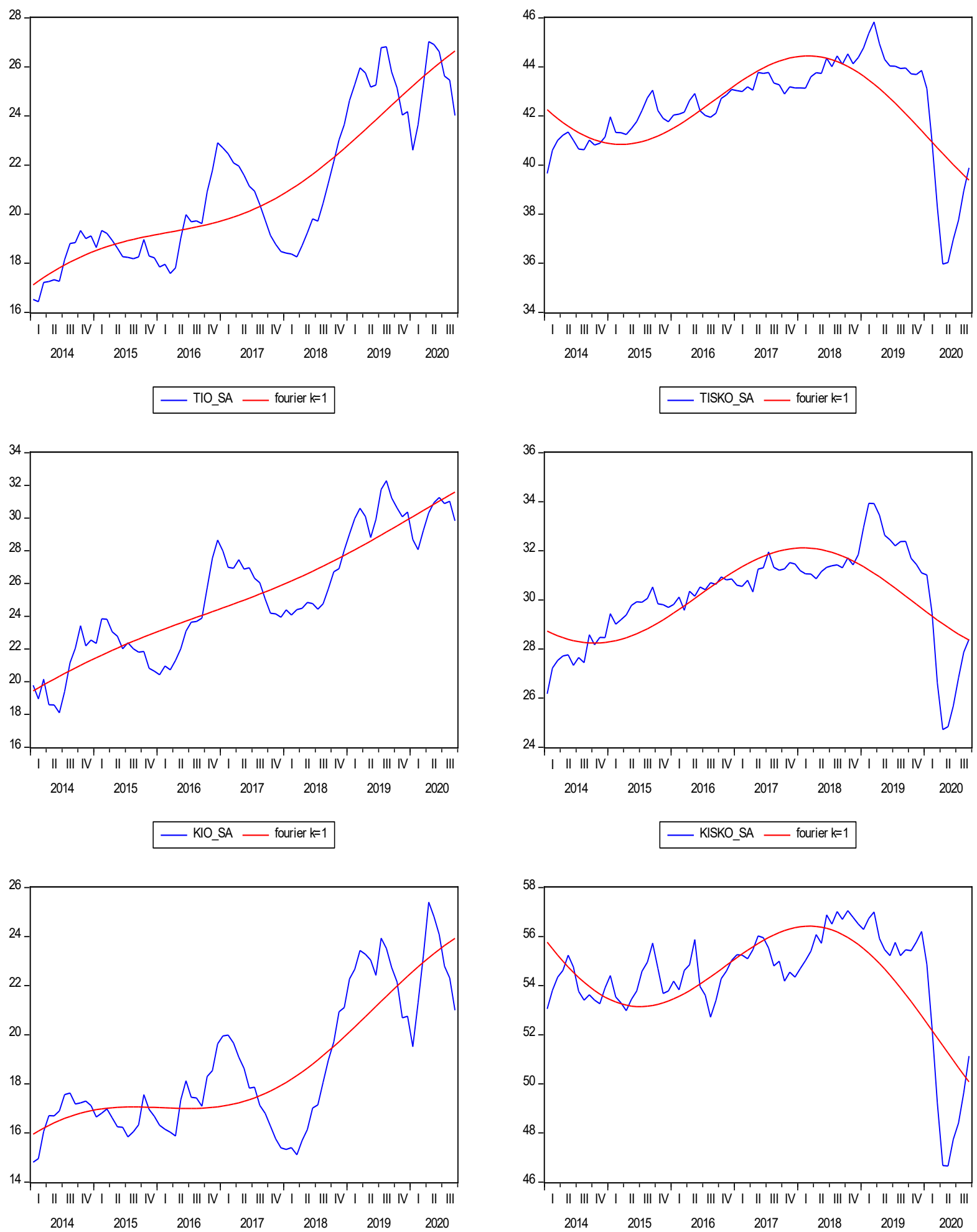

$$
\text { - ElO_SA — fourier } k=1
$$

$$
\text { - EISKO_SA — foruier } k=1
$$

Şekil 3. Fourier Fonksiyonlarının Grafikleri $(\mathrm{K}=1)$ 

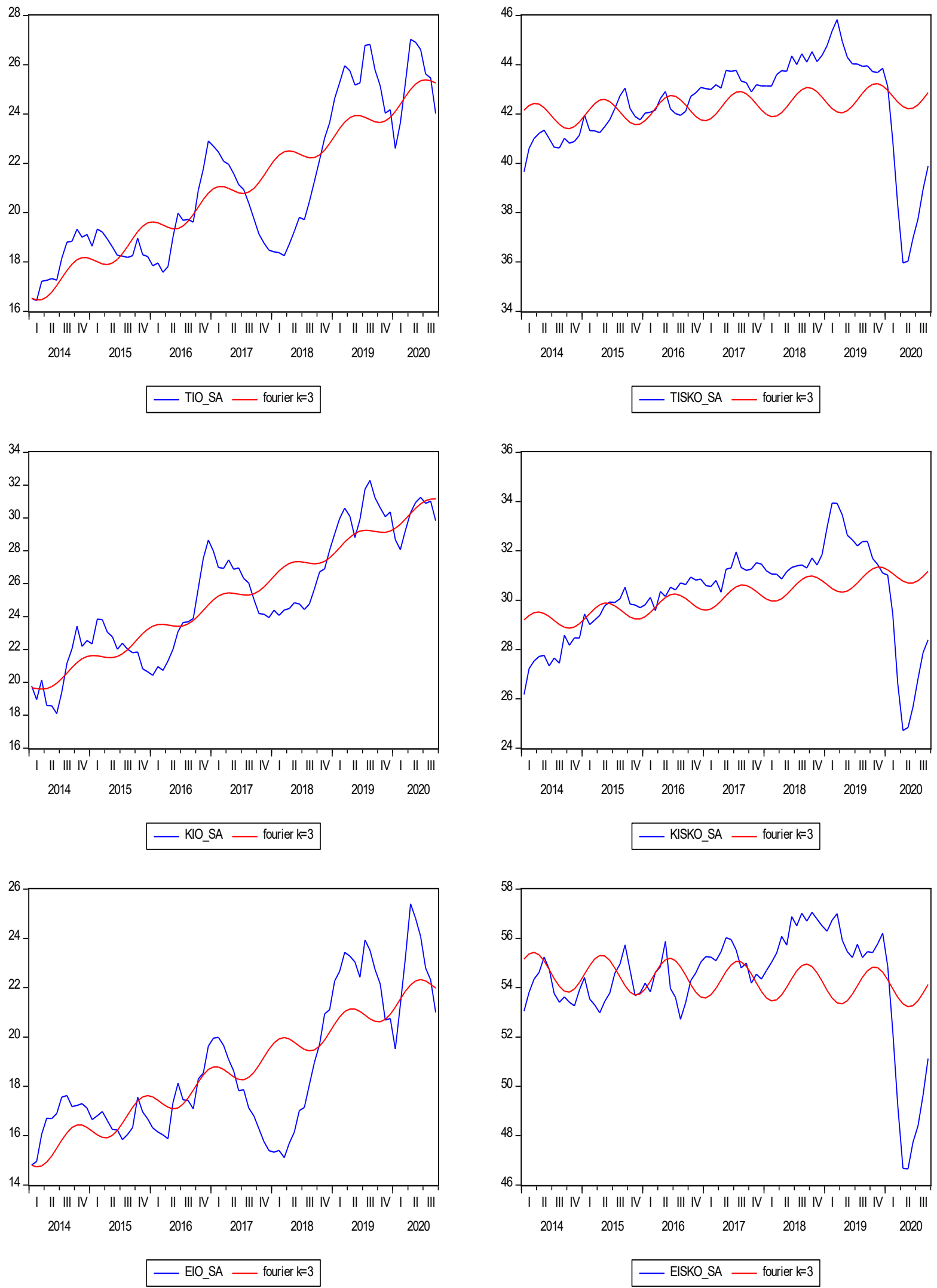

Şekil 4. Fourier Fonksiyonlarının Grafikleri (k=3) 


\section{Sonuç}

Literatürde işsizlik oranlarının ortalamasına dönme eğilimi hakkında 3 farklı görüş bulunmaktadır. Bunlar, doğal oran hipotezi, işsizlik histerisi ve yapısalcı yaklaşımlardır. Doğal oran hipotezine göre, işsizlik oranlarının ortalamasına dönme eğiliminde olacaktır. İşsizlik oranlarının ortalamasına dönmediği durumu tartışan görüş ise işsizlik histerisidir. Yapısal kırılmaları dikkate altında işsizlik oranlarının ortalamasına döndüğünü iddia eden yapısalcı yaklaşıma göre, işsizlik oranları bazı şoklar karşısında dengeden uzaklaşsa da uzun dönemde tekrar ortalamasına dönme eğilimindedir ve bu durum çok nadir ve az sayıda şok karşısında seri ortalamasına dönmeme eğiliminde olabilir.

$\mathrm{Bu}$ görüşler 1şı̆ğnda, literatürde birim kök testinden yararlanarak genç nüfusta işsizlik serisinin durağanlığı araştırılmaktadır. Bu çalışmada ilk olarak geleneksel bir birim kök testi olan ADF testinden yararlanılmış olup, 15-24 yaş grubundaki nüfusun cinsiyete dayalı işe katılım oranı ve işsizlik oranı 2014:01-2020:09 arası aylık verileriyle çalışılmıştır.

Elde edilen bulgulara göre, işsizlik oranı ve işe katılım oranı serileri seviyede durağan değildir. Bu durum işsizlik histerisinin genç nüfusta geçerli olabileceğini göstermektedir. Ancak, yapısalcı yaklaşım yapısal kırılmaların dikkate alınmasıyla doğal oran hipotezinin geçerli olabileceğini iddia ettiğinden yapısal kırılmaları da dikkate alan birim kök testlerinin de (Zivot \& Andrews, 1992; Narayan \& Popp, 2010) uygulanması gerektiği sonucu ortaya çıkmıştır. Böylece, yapısalcı yaklaşımın da geçerli olup olmadığının araştırılmasından sonra nihai sonuca varılması ve işsizlik histerisinden böyle bir durumda söz edilebileceği sonucuna varılmıştır.

Ani kırılmaları dikkate alan tek kırılmalı ADF test stratejisine dayanan Zivot ve Andrews (1992) ve iki kırılmalı ADF test stratejisine dayanan Narayan ve Popp (2010) test sonuçlarına göre ise seriler seviyede durağandır. Bu durum, Çemrek ve Şeker (2020) sonuçlarıyla uyumlu bir şekilde yapısalcı görüşü desteklemektedir. Ancak Enders ve Lee (2012), fourier ADF test sonuçlarına göre, sabitte kırılmanın olduğu model için sonuçlar ADF test istatistiğini destekler nitelikte, \%5 önem düzeyi için seviyede durağan olmadığı yönündedir. Ancak, sabitin ve trendin modele dahil edildiği test istatistiğinde kadın istihdama katılım oranı hariç diğer serilerin birim kök içerdiği yönündeki boş hipotez \%5 önem düzeyinde reddedildiğinden, yapısalcı yaklaşım geçerlidir. 
Serilerin grafikleri incelendiğinde yumuşak kırılmalardan ziyada ani kırılmaların varlığı dikkat çektiğinden, yapısalcı yaklaşımın geçerli olma olasılığı daha yüksek olup, işsizlik histerisinin genç nüfustaki varlığı teste göre değiştiğinden kesin bir yargıya varmak zordur. Ancak doğal oran hipotezi geçerli olmayıp, serilerin ortalamaya dönme eğilimi ancak kırılmaların varlığını dikkate aldığımızda gerçekleştiğinden bulguların, yapısalcı yaklaşımı ve işsizlik histerisini beraber destekler yönde karışık bulgular olduğu söylenebilir. 


\section{Kaynakça}

Akcan, A. T. (2019). Türkiye'de gençlerin işsizlik histerisi. Kastamonu Üniversitesi İktisadi ve İdari Bilimler Fakültesi Dergisi, 21(1), 31-47.

Barışık, S. \& Çevik, E. İ. (2008). Yapısal kırılma testleri ile Türkiye'de işsizlik histerisinin analizi: 1923-2006 dönemi. Karamanoğlu Mehmetbey Üniversitesi İktisadi ve İdari Bilimler Fakültesi Dergisi, (14), 109-134.

Blanchard, O. J. \& Summers, L. H. (1986). Hysteresis and the European unemployment problem. NBER Macroeconomics Annual, 1, 15-78.

Campbell, J. Y. \& Mankiw, N. G. (1987). Are output fluctuations transitory?. The Quarterly Journal of Economics, 102(4), 857-880.

Çınar, M., Akay, H. \& Yılmaz, F. (2014). A sectoral analysis of hysteresis in unemployment: Evidence from Turkey. Bilig, (69), 29-52.

Çemrek, F. \& Şeker, T. (2020). Türkiye'de kadın işsizlik oranlarının yapısal kırılmalı birim kök testleri ile incelenmesi. Ankara Hacı Bayram Veli Üniversitesi İktisadi ve İdari Bilimler Fakültesi Dergisi, 117-132.

Dickey, D. A. \& Fuller, W. A. (1979). Distribution of the estimators for autoregressive time series with a unit root. Journal of the American Statistical Association, 74(366a), 427-431.

Dickey, D. A. \& Fuller, W. A. (1981). Likelihood ratio statistics for autoregressive time series with a unit root. Econometrica: Journal of the Econometric Society, 1057-1072.

Enders, W. \& Lee, J. (2012). The flexible Fourier form and Dickey-Fuller type unit root tests. Economics Letters, 117(1), 196-199.

Friedman, M. (1995). The role of monetary policy. In Essential Readings in Economics (215-231) Palgrave, London.

Kahyaoğlu, H., Tuzun, O., Ceylan, F. \& Ekinci, R. (2016). İşsizlik histerisinin geçerliliğii: türkiye ve seçilmiş AB ülkeleri üzerine bir uygulama. Manisa Celal Bayar Üniversitesi Sosyal Bilimler Dergisi, 14(4), 103-128.

Narayan, P. K. \& Popp, S. (2010). A new unit root test with two structural breaks in level and slope at unknown time. Journal of Applied Statistics, 37(9), 1425-1438.

Narayan, P. K. \& Popp, S. (2013). Size and power properties of structural break unit root tests. Applied Economics, 45(6), 721-728.

Nelson, C. R. \& Plosser, C. R. (1982). Trends and random walks in macroeconmic time series: some evidence and implications. Journal of Monetary Economics, 10(2), 139-162.

Öztürk, M. (2020). Türkiye'de işsizlik histerisi hipotezinin geçerliliği: Çok boyutlu ve asimetrik yaklaşım. OPUS Uluslararası Toplum Araştırmaları Dergisi, 15(1), 4882-4910. 
Phelps, E. S. (1968). Money-Wage Dynamics and Labor-Market Equilibrium. Journal of Political Economy, 76(4, Part 2), 678-711.

Phelps, E. S. (1994). Structural Slumps: The Modern Equilibrium Theory of Unemployment, Interest, and Assets. Harvard University Press.

Saraç, T. B. (2014). Hysteresis effect in unemployment: Turkey case. Ege Akademik Baklş Dergisi, 14(3), 335-344.

Tekin, İ. (2018). Türkiye'de işsizlik histerisi: Fourier fonksiyonlu durağanlık sınamaları. Dokuz Eylül Üniversitesi İktisadi İdari Bilimler Fakültesi Dergisi, 33(1), 97-127.

Topalhan, T., Durusoy, Ö. T. \& Özdemir, Z. A. (2017). İşsizlik oranı üzerindeki şoklar gerçekten kalıcı mı: Türkiye ekonomisi üzerine bir analiz. SGD-Sosyal Güvenlik Dergisi, 7(2), 87-104.

Türkiye İstatistik Kurumu (TÜIK). İstihdam, Işsizlik ve Ücret İstatistikleri. (Erişim Tarihi: 10.12.2020)

Yılancı, V. (2011). Yapısal kırılmalar altında Türkiye için işsizlik histerisinin sınanması. Doğuş Üniversitesi Dergisi, 10(2), 324-335.

Yıldırım, S. (2011). Türkiye'de histeri hipotezinin geçerliliğinin çoklu yapısal kırılmalı CKP birim kök testiyle sınanması. Akdeniz İ̈BF Dergisi, 11(22), 28-47.

Sigeze, Ç., Coşkun, N. \& Ballı, E. (2019). AB ülkelerinde ve Türkiye'de işsizlik histerisinin Fourier-KPSS birim kök testi ile incelenmesi. İzmir İktisat Dergisi, 34(1), 15-24.

Zivot, E. \& Andrews, D. W. K. (2002). Further evidence on the great crash, the oil-price shock, and the unit-root hypothesis. Journal of Business \& Economic Statistics, 20(1), 25-44. 